\title{
PEMANFAATAN MEDIA SOSIAL SEBAGAI SISTEM DUKUNGAN SOSIAL PADA PERAWATAN PALIATIF ANAK PENDERITA KANKER: KAJIAN LITERATUR
}

\author{
Rahmatuz Zulfia ${ }^{1}$ \\ Fakultas Ilmu Keperawatan Program Studi Magister Peminatan Keperawatan Anak \\ Universitas Indonesia \\ *Email: rahmatuzulfia@gmail.com
}

\begin{abstract}
Abstrak
Media sosial banyak digunakan oleh seluruh lapisan masyarakat, termasuk para survivor kanker, orang tua, dan tenaga kesehatan. Media sosial yang merupakan internet-based resources mulai digunakan sebagai sumber pencarian informasi kesehatan dan tempat berdiskusi dengan tenaga kesehatan. Tujuan penulisan artikel ini untuk menggali potensi penggunaan media sosial di Indonesia sebagai salah satu intervensi yang diberikan oleh perawat untuk menyediakan sistem dukungan pada anak penderita kanker. Telaah literatur ini menggunakan metode systematic review dengan penelusuran literatur melalui database online Science Direct, Ebsco Host, Proquest, Scopus, Clinical Key, dan PubMed sejak tahun 2013-2018. Beberapa penelitian di Amerika Serikat, Kanada, dan Inggris menunjukkan bahwa media sosial banyak digunakan oleh tenaga kesehatan dan orang tua dalam kaitannya di bidang kesehatan terutama penanganan kanker. Media sosial efektif sebagai sistem dukungan sosial sehingga perawat perlu mengembangkan pemanfaatan media sosial ke dalam intervensi keperawatan paliatif.
\end{abstract}

Kata Kunci : media sosial, dukungan sosial, anak dengan kanker

\begin{abstract}
Social media is widely used by all levels of society, including cancer survivors, parents, and health workers. Social media which is internet-based resources began to be used as a source of health information search and a place for discussion with health workers. The purpose of this article is to explore the potential of using social media in Indonesia as one of the interventions provided by nurses to provide a support system for children with cancer. This literature review uses a systematic review method with literature search through the online Science Direct, Ebsco Host, Proquest, Scopus, Clinical Key, and PubMed databases from 2013-2018. Several studies in the United States, Canada, and the United Kingdom show that social media is widely used by health workers and parents in relation to health, especially in cancer treatment. Social media is effective as a system of social support so nurses need to develop the use of social media into palliative nursing interventions.
\end{abstract}

Keywords : social media, social support, children with cancer 


\section{Pendahuluan}

Saat ini kanker pada anak menjadi salah satu penyakit yang mengancam di seluruh dunia. Data yang diperoleh dari Union for International Cancer Control (UICC) menunjukkan bahwa 176.000 anak di negara berpenghasilan rendah dan menengah mendapat diagnosa kanker setiap tahunnya. Kanker menjadi penyebab kematian terbesar kedua pada anak usia 5-14 tahun di negara berpenghasilan tinggi. Sementara di Indonesia terdapat kurang lebih 11.000 kasus kanker anak per tahun (Kemenkes RI, 2015).

Kanker merupakan penyakit yang membutuhkan waktu penyembuhan relatif lama karena memerlukan prosedur pengobatan berkelanjutan yang tidak hanya dapat menimbulkan stres fisik (nyeri), namun juga berdampak pada sosialpsikologi seperti perkembangan identitas, koping, dan interaksi sosial (Chou \& Moskowitz, 2016). Kanker juga dapat dikatakan sebagai penyakit keluarga karena dampak yang ditimbulkan lebih dirasakan oleh keluarga, yaitu reaksi psikologi maladaptif yang dapat terus berlanjut apabila anak dan orang tua tidak mendapatkan dukungan sosial dari lingkungannya.

Dukungan sosial merupakan hal yang sangat penting bagi keluarga yang memiliki anak penderita kanker. Sebuah penelitian menunjukkan bahwa keluarga yang mendapatkan dukungan sosial terorganisasi memiliki koping yang lebih baik daripada keluarga yang dibiarkan sendirian menghadapi masa-masa krisisnya (Behzadi, Rassouli, \& Mojen, 2018). Kualitas pelayanan yang baik pada anak penderita kanker akan meningkatkan hasil perawatan, keberhasilan, dan kualitas hidup anak dan orang tua (Knops et al., 2012).

Komunikasi terapeutik juga sangat diperlukan oleh orang tua dan anak penderita kanker. Komunikasi yang berkualitas tinggi, akurat, dan dilakukan di waktu yang tepat harus menjadi prioritas saat berinteraksi dengan anak penderita kanker (Knops et al., 2012). Komunikasi juga dilakukan oleh perawat dalam menjalankan perannya sebagai edukator, yaitu menyampaikan dan menerjemahkan informasi kompleks yang dibutuhkan pasien dan orang tuanya (Hendricks-ferguson, Akard, Madden, Peters-herron, \& Levy, 2015). 
Sebagian besar orang tua menunjukkan kesungguhannya dalam menjalankannya perannya sebagai sumber informasi bagi anaknya dan meyakini bahwa dirinya merupakan orang yang tepat untuk berdiskusi seputar penyakit dengan anaknya (Gibson, Kumpunen, Bryan, \& Forbat, 2018). Hasil penelitian menunjukkan bahwa beberapa orang tua aktif mencari informasi yang diperlukan untuk menghilangkan ketidaktahuannya dan sekaligus meningkatkan sense of control. Informasi yang paling banyak dicari oleh orang tua meliputi penyakit, prognosis, pengobatan, efek samping, dan perawatan (Kilicarslantoruner \& Akgun-citak, 2013). Sumber yang digunakan orang tua untuk mendapatkan informasi selain dari tenaga ahli (dokter dan perawat) ialah internet, teman, ataupun sesama orang tua yang anaknya mendapatkan pengobatan serupa. Namun tidak dapat dipastikan apakah informasi yang disajikan dalam internet sesuai dengan konsep palliative care atau tidak.

Media sosial merupakan internetbased resources dan aplikasi yang memungkinkan penggunanya untuk membuat ataupun mengganti konten sesuai dengan keinginan atau kebutuhan. Keluasan bidang ilmu onkologi akan mendapatkan manfaat dari peningkatan penggunaan media sosial online, terutama untuk meningkatkan komunikasi, pendidikan, dan mentorship tenaga kesehatan (Adilman, Rajmohan, Brooks, \& Urgoiti, 2015). Media sosial juga telah banyak digunakan oleh survivor kanker (termasuk perawat) sebagai media bertukar informasi serta pemberian dukungan sosial dan emosional (Chou \& Moskowitz, 2016; Hawkins \& Carlos, 2017)). Media sosial yang digunakan sebagai tempat untuk berbagi informasi mengenai kesehatan dan untuk mencari jawaban dari rasa ingin tahu, jika tidak ada tenaga kesehatan ahli yang terlibat, maka dikhawatirkan akan terjadi kesenjangan yang disebabkan oleh penyampaian informasi dari orang nonmedis yang mungkin menyebabkan kesalahan persepsi.

Tujuan dari kajian literatur ini adalah untuk menggali potensi penggunaan media sosial di Indonesia sebagai salah satu intervensi yang diberikan oleh perawat untuk mengidentifikasi kebutuhan informasi dan emosi serta membantu menyediakan dukungan sosial pada perawatan paliatif anak penderita kanker.

\section{Metode}


Penulisan artikel ini menggunakan metode systematic review dengan melakukan penelusuran literatur melalui database online Science Direct, Ebsco Host, Proquest, Scopus, Clinical Key, dan PubMed. Literatur yang digunakan dibatasi dari tahun 2013 sampai tahun 2018 dengan kata kunci "social media AND cancer in children".

\section{Kajian Literatur}

\section{Peran Orang Tua dan Tenaga Kesehatan dalam Komunikasi}

Penelitian yang dilakukan Gibson (2018) kepada orang tua anak penderita kanker dan tenaga kesehatan profesional yang terlibat dalam proses pengobatan kanker pada anak di United Kingdom menemukan banyak ketidakcocokan dalam komunikasi orang tua-tenaga kesehatan, dimana pihak pencari dan penyedia informasi memiliki tujuan berbeda. Tenaga kesehatan profesional yang memang sudah memiliki pengetahuan lebih banyak menciptakan kesenjangan saat berkomunikasi dengan orang tua yang kurang memiliki pengetahuan tentang penyakit kanker. Sebagian orang tua mengaku tidak mendapatkan informasi yang adekuat dari tenaga kesehatan di rumah sakit mengenai diagnosa kanker (Gibson et al., 2018).

\section{Evaluasi Sumber Informasi Perawatan} Paliatif yang Tersedia untuk Publik Menggunakan Internet dan Media Sosial (Claudio, Dizon, \& October, 2018)

Salah satu sumber yang digunakan oleh orang tua dalam pencarian informasi mengenai pengobatan kanker pada anak yaitu melalui internet. Sebuah penelitian cross-sectional dilakukan pada hasil pencarian kata kunci "palliative care" pada internet dan media sosial. Penelitian ini bertujuan untuk mengidentifikasi sumber yang tersedia di dalam internet dan media sosial mengenai perawatan paliatif dan menilai penyampaian informasinya. Hasil penelitian menunjukkan bahwa mesin pencarian terbesar seperti Google dan YouTube menampilkan informasi yang bermutu dan konsisten mengenai perawatan paliatif. Namun dalam pencarian tersebut tidak ada website yang menampilkan penjelasan perawatan paliatif pada anak.

\section{Penggunaan Media Sosial oleh Orang} Tua dan Tenaga Kesehatan pada Anak Penderita Kanker (Nagelhout et al., 2018)

Penelitian yang dilakukan terhadap 680 orang ahli onkologi untuk mengetahui penggunaan media sosial oleh para ahli 
onkologi berdasarkan usia. Hasil penelitian tersebut menunjukkan bahwa angka pengguna media sosial oleh ahli onkologi cukup tinggi, yaitu $93 \%$ responden usia 25 34 dan 39\% pada usia 45-54 tahun. Penelitian selanjutnya diharapkan dapat mengidentifikasi penggunaan media sosial yang dapat meningkatkan kolaborasi dan sharing ilmu melalui media sosial oleh para ahli onkologi (Adilman et al., 2015).

Penelitian yang dilakukan oleh Nagelhout (2018) menunjukkan 74\% tenaga kesehatan menggunakan media sosial dalam berinteraksi dengan anak penderita kenker. Media sosial digunakan untuk menyediakan dan menerima dukungan serta informasi yang dibutuhkan mengenai kanker dan pengobatannya.

\section{Pemanfaatan dan Efektivitas Media} Sosial pada Kesehatan Anak (Hamm et al., 2014)

Beberapa studi mengenai penggunaan dan keefektifan media sosial untuk kesehatan anak yang telah dilakukan sebelumnya menunjukkan bahwa media sosial banyak digunakan untuk promosi kesehatan (52\%) dan membentuk forum diskusi (68\%). Banyak juga peneliti yang memasukkan media sosial sebagai bagian dari intervensi. Aplikasi yang dimiliki oleh media sosial berikut pengoperasiannya dinilai efektif sebagai distraksi pada anak dan dapat dijadikan sarana komunikasi teman sebaya di kalangan remaja (Hamm et al., 2014).

\section{Pembahasan}

Menerima diagnosa kanker pada anaknya bukanlah hal yang mudah bagi orang tua. Apalagi jika orang tua tidak memiliki pengetahuan yang cukup mengenai kanker. Orang tua membutuhkan sumber informasi yang memadai yang dapat meredam ansietasnya. Perawat memiliki peran dalam membantu orang tua menghilangkan kesulitan yang dialami orang tua dalam proses penerimaan kanker anak.

Kesenjangan komunikasi antara tenaga kesehatan dan orang tua muncul karena tenaga kesehatan menyampaikan informasi sebatas hal yang menjadi fokus keilmuannya saja, misalnya dokter menyampaikan prognosis penyakit dan pengobatan yang akan dijalani, sedangkan perawat berfokus pada penyampaian tindakan keperawatan dan efek samping suatu prosedur (Gibson et al., 2018). Informasi yang adekuat dan memuaskan keingintahuan sangat diperlukan orang tua dalam proses pengobatan kanker yang 
dijalani anaknya sehingga dapat menurunkan tingkat stres yang dirasakan orang tua.

Banyak cara yang dapat dilakukan oleh tenaga kesehatan dalam memanfaatkan media sosial untuk menyediakan informasi yang dibutuhkan pasien dan orang tua. Salah satunya yaitu dengan menyediakan forum diskusi untuk orang tua maupun perawat yang memberikan pelayanan kesehatan pada anak kanker untuk bertukar pengalaman dan informasi yang relevan. Media sosial berpotensi dalam meningkatkan pelayanan kesehatan dengan memfasilitasi perawat menyampaikan gagasan sesuai fokus keilmuannya dan juga menyediakan informasi dalam suatu komunitas kesehatan, dengan pasien, atau dengan masyarakat umum.

Media sosial selain dapat dijadikan sebagai sumber pencarian informasi yang diperlukan oleh orang tua, juga dapat diisi dengan pengajaran manajemen nyeri nonfarmakologi. Anak penderita kanker yang mendapatkan pengobatan hampir seluruhnya melaporkan keluhan nyeri yang dapat menimbulkan stres pada orang tuanya (Bettle, Latimer, Fernandez, \& Hughes, 2018). Perawat dapat berperan dalam pemantauan dan evaluasi tindakan manajemen nyeri non farmakologi yang dilakukan orang tua di rumah melalui media sosial.

Berdasarkan hasil penelitian yang menunjukkan pengaruh positif pemanfaatan media sosial, maka media sosial yang menyediakan sistem dukungan sosial dapat direkomendasikan sebagai salah satu intervensi khusunya pada perawatan paliatif anak dengan kanker. Hal ini diharapkan dapat diimplementasikan ke dalam asuhan keperawatan secara terorganisir dan dapat dievaluasi untuk menilai keefektifan tindakan.

\section{Kesimpulan}

Berdasarkan telaah literatur, media sosial dapat dijadikan acuan dalam pencarian intervensi keperawatan untuk menemukan kebutuhan informasi dan emosi yang diperlukan oleh perawat dalam memberikan perawatan pada anak penderita kanker. Melalui media sosial perawat juga dapat memberikan dukungan pada orang tua dengan memilihkan sumber dukungan yang terpercaya yang mudah diakses melalui media sosial.

Perawat perlu melakukan identifikasi dan penelitian lebih mendalam untuk menemukan tools yang sesuai dan efektif untuk diaplikasikan dalam perawatan paliatif pada anak penderita kanker yang melibatkan orang tua. Tentu saja 
penggunaan media sosial dalam pelayanan keperawatan harus memperhatikan keamanan dan kelayakan etik.

\section{Referensi}

Adilman, B. R., Rajmohan, Y., Brooks, E., \& Urgoiti, G. R. (2015). Original

Contribution Social Media Use Among Physicians and Trainees : Results of a National Medical Oncology Physician Survey. Journal of Oncology Practice, $1-6$.

Behzadi, M., Rassouli, M., \& Mojen, L. K. (2018). Posttraumatic Growth and Its Dimensions in the Mothers of Children with Cancer, 6(3), 209-217.

Bettle, A., Latimer, M., Fernandez, C., \& Hughes, J. (2018). Supporting Parents ' Pain Care Involvement With Their Children With Acute Lymphoblastic Leukemia : A Qualitative Interpretive Description. https://doi.org/10.1177/1043454217727 518

Chou, W. S., \& Moskowitz, M. (2016). ScienceDirect Social media use in adolescent and young adult ( AYA ) cancer survivors. Current Opinion in

Psychology, 9, 88-91.

https://doi.org/10.1016/j.copsyc.2016.0 1.003

Claudio, C. H., Dizon, Z. B., \& October, T. W. (2018). Evaluating Palliative Care Resources Available to the Public Using the Internet and Social Media. American Journal of Hospice \& Palliative Medicine ${ }^{\circledR}, 20(2), 1-7$. https://doi.org/10.1177/1049909118763 800

Gibson, F., Kumpunen, S., Bryan, G., \& Forbat, L. (2018). Insights from parents of a child with leukaemia and healthcare professionals about sharing illness and treatment information : A qualitative research study. International Journal of Nursing Studies, 83(January), 91-102. https://doi.org/10.1016/j.ijnurstu.2018. 04.008

Hamm, M. P., Shulhan, J., Williams, G., Milne, A., Scott, S. D., \& Hartling, L. (2014). A systematic review of the use and effectiveness of social media in child health. BMC Pediatrics, 14(1), 115. https://doi.org/10.1186/1471-243114-138 
Hawkins, C. M., \& Carlos, R. C. (2017).

Exploring Social Media in Health

Care : Beyond Its Pervasiveness.

Journal of the American College of

Radiology, 15(1), 133-134.

https://doi.org/10.1016/j.jacr.2017.09.0

38

Hendricks-ferguson, V. L., Akard, T. F., Madden, J. R., Peters-herron, A., \&

Levy, R. (2015). Contributions of

Advanced Practice Nurses With a DNP

Degree During Palliative and End-of-

Life Care of Children With Cancer.

https://doi.org/10.1177/1043454214555

195

Kilicarslan-toruner, E., \& Akgun-citak, E.

(2013). European Journal of Oncology

Nursing Information-seeking

behaviours and decision-making

process of parents of children with

cancer. European Journal of Oncology

Nursing, 17(2), 176-183.

https://doi.org/10.1016/j.ejon.2012.03.0

01

Knops, R. R. G., Hulscher, M. E. J. L.,

Hermens, R. P. M. G., Loeffen, J. L.,

Kollen, W. J. W., Kaspers, G. J. L., ...

Kremer, L. C. M. (2012). High-quality

care for all children with cancer.

Annals of Oncology, (February), 1906-
1911.

https://doi.org/10.1093/annonc/mdr601

Nagelhout, E. S., Linder, L. A., Austin, T.,

Parsons, B. G., Scott, B., Gardner, E.,

... Wu, Y. P. (2018). Social Media Use

Among Parents and Caregivers of

Children With Cancer. Journal of

Pediatric Oncology Nursing, 1-7.

https://doi.org/10.1177/1043454218795

091 